Original Article

\title{
CHARACTERIZATION, IN VITRO ANTIOXIDANT AND HEPATOPROTECTIVE ACTIVITY OF FUNGAL ENDOPHYTIC EXTRACTS OF ANDROGRAPHIS PANICULATA LEAVES IN CCL 4 INDUCED HEPATOTOXICITY
}

\author{
SMITA K. PURI ${ }^{*}$, PRASANNA V. HABBU ${ }^{1}$, PREETI V. KULKARNI², VENKATRAO H. KULKARNI ${ }^{2}$
}

1PG Depatment of Pharmacognosy and Phytochemistry, SET's College of Pharmacy, S R Nagar, Dharwad 580002, Karnataka, India, ${ }^{2}$ PG Department of Pharmacology, SET's College of Pharmacy, S R Nagar, Dharwad 580002, Karnataka, India

Email: smitamadagundi@gmail.com

Received: 28 Apr 2018 Revised and Accepted: 23 Nov 2018

\begin{abstract}
Objective: To isolate and characterize the endophytic fungi from the leaves of Andrographis paniculata for free radical scavenging antioxidant and hepatoprotective activity against $\mathrm{CCl}_{4}$ induced hepatotoxicity

Methods: Two fungal endophytes, APLF-3 (Andrographis paniculata leaf fungi-3) and APLF-4 (Andrographis paniculata leaf fungi-4) were isolated from leaves of Andrographis paniculata to get chloroform (A3C, A4C), ethyl acetate (A3EA, A4EA) and n butanol (A3nB, A4nB) extracts. rDNA sequencing by PCR technique was carried out for identification of APLF-3 and APLF-4. All the APLF-3 and APLF-4 extracts were assayed for in vitro free radical scavenging activity against 2, 2-diphenyl-1-picrylhydrazyl (DPPH), hydroxyl radical and reducing power. Then, A4EA and A4nB were screened for hepatoprotective activity against $\mathrm{CCl}_{4}$ induced hepatotoxicity at $50 \mathrm{mg} / \mathrm{kg}$ and $100 \mathrm{mg} / \mathrm{kg}$ doses.
\end{abstract}

Results: The endophytic fungi, APLF-3 and APLF-4, were identified as Phyllosticta sp. ZLY-2010 isolate M13 and Aspergillus tubingensis strain Cs/7/2 respectively based on their morphological and molecular characterization. A4EA and A4nB showed significant in vitro free radical scavenging activity as compared to other extracts. A4EA and A4nB $(50 \mathrm{mg} / \mathrm{kg}$ and $100 \mathrm{mg} / \mathrm{kg})$ reversed the increased serum biochemical parameters as compared to $\mathrm{CCl}_{4}$ treated group $(\mathrm{p}<0.001)$. A4EA and $\mathrm{A} 4 \mathrm{nB}(100 \mathrm{mg} / \mathrm{kg} \mathrm{p}$. o) also restored the LPO, SOD and CAT levels.

Conclusion: These findings suggested that the extracts (A4EA and A4nB) obtained from endophytic fungi APLF-4 contributed towards hepatoprotective activity.

Keywords: Endophytic fungi, Hepatoprotective, Antioxidant, Andrographis paniculata, Phyllosticta sp. ZLY-2010 isolate M13, Aspergillus tubingensis strain $C s / 7 / 2$

(c) 2019 The Authors. Published by Innovare Academic Sciences Pvt Ltd. This is an open-access article under the CC BY license (http://creativecommons.org/licenses/by/4.0/) DOI: http://dx.doi.org/10.22159/ijpps.2019v11i1.26832

\section{INTRODUCTION}

Medicinal plants are used traditionally for treating several disorders, such as gastrointestinal manifestation, skin disorders, cardiovascular and hepatic diseases [1]. Plants rely on their microbes for specific characters and pursuits that include plant growth promotion and tolerance to abiotic stress factors [2]. Endophytes are the microorganisms such as bacteria, fungi, and actinomycetes, residing in the interior of the plant tissues showing no deleterious causes. Endophytes show varied relationships from symbiotic, mutualistic, communalistic to trophobiotic [3]. They produce good adaptability of the plants in ecology. These endophytes produce a variety of secondary metabolites for applications in agriculture, medicine and in biotechnological industries. In pharmaceutical industries, endophytes act an alternative source for the production of novel drug molecules and help in drug resistance showing the alternate source of drugs [4]. Among different endophytes, endophytic fungi are found to be potential for synthesizing various bioactive compounds and can be used against numerous diseases [5]. Endophyte Epichloe festucae var. lolii was isolated from grass which produced alkaloids protecting the host grass Lolium perenne from herbivory [6]. The organ responsible for metabolizing foreign particle, synthesize proteins, secrete enzymes and detoxify xenobiotics, is liver. Liver diseases are caused due to alcoholic consumption, anemia, malnutrition, iron deficiency, and accessibility of hepatotoxic medications over the counter. The routine medications utilized may be deficient causing antagonistic impacts. Thus, the availability of drugs become limited and has challenges for developing novel drugs with potentiality [7]. Need for novel and effective bioactive compounds are much needed for mankind which are safe over synthetic compounds. In recent days endophytic fungi have been used as a source of secondary metabolites [8]. Andrographis paniculata Nees (Kalmegh) (family; Acanthaceae) is a medicinal plant widely used in treating the liver infections [9]. The plant contains phytoconstituents as such diterpenoids, stigmasterols, flavonoids, andrographolides [10]. Andrographolide and neoandrographolide have been reported to be helpful in liver disorders [11]. Apart from this, endophytic fungi, such as Aspergillus niger, Aspergillus flavus, etc were also reported from different parts of the Andrographis paniculata [12]. And as on now, no work has been reported on the antioxidant and hepatoprotective activity associated with endophytic fungi of Andrographis paniculata leaves. Hence, the present study was designed for the same.

\section{MATERIALS AND METHODS}

\section{Chemical and reagents}

Carbon tetrachloride was purchased from SD Fine Chemicals, Mumbai. DPPH, Deoxy D-ribose was obtained from Himedia Laboratories, Mumbai, India. Silymarin from Microlab, Bangalore, India. AST, ALT, ALP, total and direct bilirubin, and total triglyceride were determined by commercially available kits from Swemed diagnostics, Bengaluru, India. All other chemicals were of analytical grade and used as received.

\section{Plant material}

The leaves of Andrographis paniculata (Burm. f.) Wall. Nees were collected from Dharwad district, Karnataka, India. The plant was authenticated by Dr. G R Hegde, Karnatak University, Dharwad (India). A specimen is stored in the herbarium, Postgraduate Department of Pharmacognosy (SETCPD/Ph. cog/herb/32/12/ 2015). 


\section{Isolation of endophytes}

Andrographis paniculata leaves were washed thoroughly under running tap water to remove any foreign particles adhering to it and were dried. They were then again washed under running tap water for $10 \mathrm{~min}$ and sterilized with $70 \%$ ethanol for $1 \mathrm{~min}, 1 \%$ sodium hypochlorite $(\mathrm{NaOCl})$ for $30 \mathrm{sec}$ and further cleaned by passing through two sets of sterile distilled water. After surface sterilization, leaves were cut into small pieces, $1 \mathrm{~cm}$ each, the sterile samples were placed on a plate containing potato dextrose agar (PDA) media with $250 \mu \mathrm{g} / \mathrm{ml}$ streptomycin to suppress fungal contamination. The plates were incubated at $25^{\circ} \mathrm{C} \pm 27^{\circ} \mathrm{C}$ for $7-14 \mathrm{~d}$, till the fungal mycelia started growing. Fungal colonies were picked randomly from the plates, checked for purity and grouped according to colony morphology [13]. Two pure endophytic fungi namely APLF-3 (Andrographis paniculata leaf fungi-3) and APLF-4 (Andrographis paniculata leaf fungi-4) were selected for further studies.

\section{Fermentation and extraction}

The purified isolates of APLF-3 and APLF-4 were inoculated and fermented separately into a $3000 \mathrm{ml}$ Erlenmeyer flask containing $600 \mathrm{ml}$ of potato dextrose broth (PDB). The flask was incubated at $25{ }^{\circ} \mathrm{C}-27{ }^{\circ} \mathrm{C}$ for $21 \mathrm{~d}$. Later, after $21 \mathrm{~d}$ of incubation, $500 \mathrm{ml}$ of chloroform was added to the flask and left overnight. It was then homogenized at $4000 \mathrm{rpm}$ to separate the mycelia from broth for 30 min and filtered by Whatman filter paper under vacuum. Aqueous phase obtained after chloroform extraction was further partitioned three times with equal volumes of ethyl acetate. Aqueous phase obtained after ethyl acetate extracting was further partitioned two times with equal volumes of n-butanol. The chloroform, ethyl acetate and n-butanol extracts of APLF-3 and APLF-4 were dried with vacuum rotary evaporator (Superfit Rotavap, PBU-6) and weighed $[14,15]$.

\section{Preliminary phytochemical test}

Preliminary phytochemical analysis of chloroform (A3C), ethyl acetate (A3EA) and $n$ butanol extracts (A3nB) of APLF-3 and chloroform (A4C), ethyl acetate (A4EA) and $n$ butanol extracts (A4nB) of APLF-4 were carried out to identify the group of secondary metabolites $[16,17]$.

\section{Colony morphology}

The colonies grown on the agar slant were studied by the lactophenol cotton blue staining. The characteristics were compared with the known organisms from the literature [18].

\section{Molecular characterization by PCR sequential analysis}

Using the genomic DNA extraction kit, genomic DNA was isolated from the given organism (Bhat Biotech Ltd. Bangalore, India) [19, 20]. Amplification of the 16s rRNA gene was performed using the primers i. e the forward primer, 5'-TCCGTAGGTGAACCTGCGG-3' and reverse primer 5'-TCCTCCGCTTATTGATATGC-3'. PCR was performed by using the following method. A total volume of $50 \mu \mathrm{l}$ was taken in a $0.2 \mathrm{ml}$ thin-walled PCR tube. Master cycler ${ }^{\circledR}$ Thermocycler (DNA-AMP Bhat Biotech) was used for amplification. Initial denaturation was carried out at $95^{\circ} \mathrm{C}$ for 10 min followed by 35 cycles of denaturation at $94^{\circ} \mathrm{C}$ for one min, annealing at $56^{\circ} \mathrm{C}$ for one min and extension at $72{ }^{\circ} \mathrm{C}$ for one min. Final extension was carried out at $72{ }^{\circ} \mathrm{C}$ for $10 \mathrm{~min}$. The PCR products from ITS gene PCR reactions were purified to remove unincorporated dNTPS and primers before sequencing using GENEASY GEL ELUTION KIT. Both strands of the rDNA region amplified by PCR were sequenced by automated DNA sequence-3037xl DNA analyzer from Applied Biosystems using BigDye ${ }^{\circledR}$ Terminator v3.1 cycle sequencing Kit (Applied Biosystems). Sequence data were aligned and dendrograms were generated using Sequence analysis software version 5.2 from applied biosystems. Appropriate software was used to align sequences acquired for plus and minus strands before to phylogenetic analysis. Sequences were compared to the nonredundant NCBI database using BLAST N. The expected value and e values were noted for the most similar sequences. Ten similar neighbors were aligned using CLUSTAL W2. The multiple-alignment file thus obtained was then used to create a Phylogram using the MEGA5 software [21, 22].

\section{High-performance thin layer chromatography of A4EA AND A4NB}

A4EA and A4nB (500 mg) extracts were dissolved in $1 \mathrm{ml}$ of ethyl acetate and n-butanol respectively. $3 \mu \mathrm{l}$ and $6 \mu \mathrm{l}$ of the above extracts were applied on a pre-coated silica gel F254 on aluminum plates to a bandwidth of $7 \mathrm{~mm}$ using Linomat 5 TLC applicator. The plate was developed in Toluene and Ethyl acetate in ratio 1:1. The developed plates were visualized in short UV, long UV and then derivatized with vanillin-sulphuric acid and scanned under UV 254 $\mathrm{nm}, 366 \mathrm{~nm}$, and $620 \mathrm{~nm}$. Rf value of the spots and densitometric scan were recorded $[23,24]$.

\section{In vitro free radical scavenging activity}

\section{Reaction with DPPH radical}

DPPH free radical scavenging activity was carried out for all the extracts of APLF-3 and APLF-4 at different concentrations [25].

\section{Reaction with hydroxyl radical}

Hydroxyl radicals were generated by a Fenton reaction (Fe3+ascorbate-EDTA- $\mathrm{H}_{2} \mathrm{O}_{2}$ system), by using the extracts of APLF-3 and APLF-4, the scavenging capacity for the hydroxyl radicals was measured using deoxyribose method [26].

\section{Determination of reducing power}

Extracts of APLF-3 and APLF-4 were subjected to reducing power by the method described by Oyaizu 1986 [27].

\section{Hepatoprotective activity}

Based on the results of in vitro free radical scavenging activity, A4EA and $\mathrm{A} 4 \mathrm{nB}$ were further selected and screened for in vivo hepatoprotective activity in $\mathrm{CCl}_{4}$ induced hepatotoxicity.

\section{Animals}

Healthy albino wister rats weighing $150-200 \mathrm{~g}$ were used. The inbred rats were collected from Venkateshwara Enterprises Bangalore, Karnataka. They were maintained in the animal house of SET's College of Pharmacy, Dharwad for the experimental purpose under controlled conditions of temperature $\left(23 \pm 2{ }^{\circ} \mathrm{C}\right)$, humidity $(50 \pm 5 \%)$ and $12 \mathrm{~h}$ light-dark cycles. They were acclimatized for $7 \mathrm{~d}$ before the study. Animals were then randomized into groups and housed individually in sanitized polypropylene cages containing sterile paddy husk as bedding. They had free access to standard pellets as basal diet and water ad libitum (Reg No.112/1999/CPCSEA,dated 19-05-1999).

\section{Acute toxicity studies}

Acute oral toxicity of A4EA and A4nB was determined using Swiss albino mice. The animals were fasted for $12 \mathrm{~h}$ prior to the experiment and were administered with single dose of extracts dissolved in 5\% gum acacia and observed for mortality up to $48 \mathrm{~h}$ (short-term toxicity). Based on the short-term toxicity, the dose of the next animal was determined as per OECD guideline 420 .

Experimental design for $\mathrm{CCl}_{4}$ induced hepatotoxicity [28].

Animals were divided into following groups of six animals in each group ( $\mathrm{n}=6)$

Group I. Normal control, Rats received a single daily dose of $0.5 \%$ Tween $80(1 \mathrm{ml})$ on all $5 \mathrm{~d}$ and olive oil $(1 \mathrm{ml} / \mathrm{kg}) \mathrm{s}$. c.

Group II. $\mathrm{CCl}_{4}$ control, Rats received $\mathrm{CCl}_{4}(2 \mathrm{ml} / \mathrm{kg}$ i. p. in olive oil)

Group III. Rats received Silymarin $(100 \mathrm{mg} / \mathrm{kg} \mathrm{p}$. o) for all $5 \mathrm{~d}$ with a single dose of $\mathrm{CCl}_{4}(2 \mathrm{ml} / \mathrm{kg})$ s. c., on $2^{\text {nd }}$ and $3^{\text {rd }}$ day, $30 \mathrm{~min}$ after Silymarin administration.

Group IV. Rats received A4EA (50 mg/kg p. o), for all $5 \mathrm{~d}$ and a single dose of $\mathrm{CCl}_{4}(2 \mathrm{ml} / \mathrm{kg})$ s. c., on $2^{\text {nd }}$ and $3^{\text {rd }}$ day, 30 min after A4EA administration. 
Group V. Rats treated with A4EA (100 mg/kg p. o), for all $5 \mathrm{~d}$ and a single dose of $\mathrm{CCl}_{4}(2 \mathrm{ml} / \mathrm{kg}) \mathrm{s}$. c. on on $2^{\text {nd }}$ and $3^{\text {rd }}$ day, $30 \mathrm{~min}$ after A4EA administration.

Group VI. Rats treated with $\mathrm{A} 4 \mathrm{nB}$ ( $50 \mathrm{mg} / \mathrm{kg} \mathrm{p.} \mathrm{o),} \mathrm{for} \mathrm{all} 5 \mathrm{~d}$ and a single dose of $\mathrm{CCl}_{4}(2 \mathrm{ml} / \mathrm{kg}) \mathrm{s}$. c, on $2^{\text {nd }}$ and $3^{\text {rd }}$ day, 30 min after $\mathrm{A} 4 \mathrm{nB}$ administration.

Group VII. Rats treated with $\mathrm{A} 4 \mathrm{nB}$ (100 mg/kg p. o), and a single dose of $\mathrm{CCl}_{4}(2 \mathrm{ml} / \mathrm{kg}) \mathrm{s}$. c, on $2^{\text {nd }}$ and $3^{\text {rd }}$ day, $30 \mathrm{~min}$ after $\mathrm{A} 4 \mathrm{nB}$ administration.

During the treatment, rats were maintained under normal diet and water ad libitum. On the $6^{\text {th }}$ day, animals were sacrificed, blood was collected by retro-orbital bleeding under mild ether anesthesia, centrifuged (3000 rpm for $15 \mathrm{~min}$ ) and serum was subjected to biochemical estimations. The liver was dissected and placed in $10 \%$ formalin solution for histopathological study. The liver homogenate was prepared to determine the levels of endogenous enzymes.

\section{Biochemical parameters}

Serum separated was analyzed spectrophotometrically for AST, ALT, ALP, total and direct bilirubin, total triglyceride (TG), and total protein using diagnostic kits of Swemed diagnostics, Bengaluru, India.

\section{Measurement of enzymatic and non-enzymatic antioxidant parameters}

\section{Tissue preparation}

Animals were sacrificed and perfused transcardially with ice-cold saline. The whole liver was perfused in situ with ice cold saline, dissected out, blotted dry and immediately weighed. A 10\% liver homogenate was prepared separately with ice-cold saline-EDTA using Teflon-glass homogenizer (Yamato LSG LH-21, Japan). The homogenate was used for the estimation of proteins and lipid peroxidation. Liver homogenate was centrifuged at $10,000 \mathrm{rpm}$ for $10 \mathrm{~min}$ and the pellet discarded. The supernatant was again centrifuged at $20,000 \mathrm{rpm}$ for $1 \mathrm{~h}$ at $4^{\circ} \mathrm{C}$. Both the liver supernatants obtained were used for the estimation of nonenzymatic antioxidants (Lipid peroxidation) and enzymatic antioxidants (Catalase and Superoxide dismutase).

\section{Lipid peroxidation}

The concentration of thiobarbituric acid reactive substances (TBARS) in the liver homogenate was estimated using the standard procedure. Briefly, the homogenate was incubated with 15\% TCA, $0.375 \% \mathrm{TBA}$ and $5 \mathrm{~N} \mathrm{HCl}$ at $95^{\circ} \mathrm{C}$ for $15 \mathrm{~min}$; the mixture was cooled, centrifuged and the absorbance of the supernatant measured at 532 $\mathrm{nm}$ against appropriate blank. The amount of lipid peroxidation was determined by using the formula $€=1.56 \times 105 \mathrm{M}^{-1} \mathrm{~cm}^{-1}$ and expressed as TBARS $(\mu)$ per gram of tissue [29].

\section{SOD assay}

To liver homogenate $(0.5 \mathrm{ml}), 1 \mathrm{ml}$ of $50 \mathrm{mmol}$ sodium carbonate, $0.4 \mathrm{ml}$ of $24 \mu \mathrm{m} \mathrm{NBT}$, and $0.2 \mathrm{ml}$ of $0.1 \mathrm{mmol}$ EDTA were added. The reaction was initiated by adding $0.4 \mathrm{ml}$ of $1 \mathrm{mmol}$ hydroxylamine hydrochloride. Zero time absorbance was taken at $560 \mathrm{~nm}$ followed by recording the absorbance after $5 \mathrm{~min}$ at $25^{\circ} \mathrm{C}$. The control was simultaneously run without liver homogenate. Units of SOD activity were expressed as the amount of enzyme required to inhibit the reduction of NBT by $50 \%$. The specific activity was expressed in terms of units per mg of proteins [30].

\section{Catalase}

To $1.95 \mathrm{ml}$ of $10 \mathrm{mmol} \mathrm{H}_{2} \mathrm{O}_{2}$ in $60 \mathrm{mmol}$ phosphate buffer $(\mathrm{pH}=7.0)$, $0.05 \mathrm{ml}$ of the liver homogenate was added, and the rate of degradation of $\mathrm{H}_{2} \mathrm{O}_{2}$ was followed at $240 \mathrm{~nm} / \mathrm{min}$. Catalase content in terms of $\mathrm{U} / \mathrm{mg}$ of protein was estimated from the rate of decomposition of $\mathrm{H}_{2} \mathrm{O}_{2}$ using the formula.

\section{$\mathrm{k}=2.303 / \Delta \mathrm{t} \times \log (\mathrm{A} 3 / \mathrm{A} 4) \mathrm{s}-1$}

A unit of catalase is defined as the quantity which decomposes 1.0 $\mu$ mole of $\mathrm{H}_{2} \mathrm{O}_{2}$ per min at $\mathrm{pH}=7.0$ at $25^{\circ} \mathrm{C}$, while $\mathrm{H}_{2} \mathrm{O}_{2}$ concentration falls from 10.3 to $9.2 \mathrm{mmol}$ [31].

\section{Estimation of protein}

Folin phenol reagent method was used to measure total tissue protein content as reported earlier [32]

\section{Histopathological studies}

Liver of individual animal was excised, fixed in $10 \%$ buffered neutral formalin and fixed in bovine solution. They were further processed for paraffin embedding following standard microtechnique [33]. Sections of liver stained with alum-hematoxylin and eosin were observed photomicroscopically for histopathological changes.

\section{Statistical evaluation}

All the data were statistically evaluated by ANOVA (one way), and the differences between groups were determined by Tukey's multiple comparison tests using Graph pad prism 5.0. USA. Values were considered to be significant when $* \mathrm{P}<0.05$, ** $\mathrm{P}<0.01$, ${ }^{* * *} \mathrm{P}<0.001$. All the results were expressed as mean $\pm \mathrm{SD}$ for six rats in each group.

\section{RESULTS}

Endophytic fungi, APLF-3 and APLF-4 were isolated from Andrographis paniculata leaves (fig. 1 and fig. 2). The percentage yield of the chloroform, ethyl acetate and $n$ butanol extracts of APLF3 and APLF-4 is illustrated in table 1.

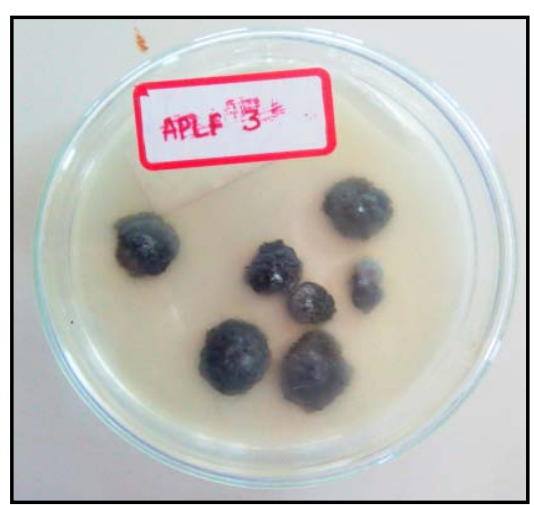

Fig. 1: APLF-3 (Andrographis paniculata leaf endophyte-3)

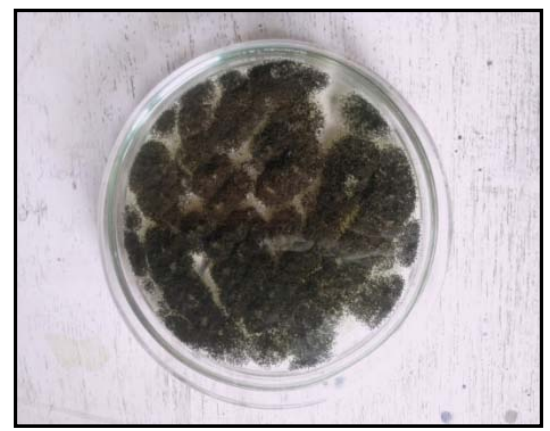

Fig. 2: APLF-4 (Andrographis paniculata leaf endophyte-4)

Table 1: Percentage yields of APLF-3 and APLF-4 extracts from 3L of fermented broth

\begin{tabular}{llll}
\hline Endophyte & Chloroform (\% yield) & Ethyl acetate (\% yield) & n-butanol (\% yield) \\
\hline APLF-3 & $2.3 \%$ & $4.0 \%$ & $3.5 \%$ \\
APLF-4 & $2.2 \%$ & $2.6 \%$ & $7.0 \%$ \\
\hline
\end{tabular}




\section{Preliminary phytochemical analysis}

Preliminary phytochemical analysis of $\mathrm{A} 3 \mathrm{C}$ and $\mathrm{A} 4 \mathrm{C}$ showed the presence of carbohydrates, alkaloids and tannins. A3EA, A4EA, A3nB and $\mathrm{A} 3 \mathrm{nB}$ showed the presence of carbohydrates, flavonoids and tannins as chief secondary metabolites.

\section{DPPH assay}

The $\mathrm{IC}_{50}$ values for $\mathrm{A} 3 \mathrm{C}, \mathrm{A} 3 \mathrm{EA}$ and $\mathrm{A3nB}$ were found to be 189 $\mu \mathrm{g} / \mathrm{ml}, 86.59 \mu \mathrm{g} / \mathrm{ml}$ and $173.33 \mu \mathrm{g} / \mathrm{ml}$ respectively whereas $\mathrm{IC}_{50}$ value for ascorbic acid was found to be $32.53 \mu \mathrm{g} / \mathrm{ml}$. The $\mathrm{IC}_{50}$ values for $\mathrm{A} 4 \mathrm{C}, \mathrm{A} 4 \mathrm{EA}$ and $\mathrm{A} 4 \mathrm{nB}$ extract were found to be 87.08 $\mu \mathrm{g} / \mathrm{ml}, 57.79 \mu \mathrm{g} / \mathrm{ml}$ and $48.48 \mu \mathrm{g} / \mathrm{ml}$ respectively whereas $\mathrm{IC}_{50}$ value for ascorbic acid was found to be $32.53 \mu \mathrm{g} / \mathrm{ml}$ (fig. 3). APLF4 extracts showed significant scavenging activity as compared to APLF-3 extracts.

\section{Hydroxyl scavenging assay}

The assay showed the abilities of the extract and standard mannitol to inhibit hydroxyl radical-mediated deoxyribose degradation in a $\mathrm{Fe} 3+-E D T A-M a n n i t o l$ and $\mathrm{H}_{2} \mathrm{O}_{2}$ reaction mixture. The $\mathrm{IC}_{50}$ values for A3C, A3EA and A3nB were found to be $614.76 \mu \mathrm{g} / \mathrm{ml}, 322.68 \mu \mathrm{g} / \mathrm{ml}$ and $283.03 \mu \mathrm{g} / \mathrm{ml}$ respectively. The $\mathrm{IC}_{50}$ values for A4C, A4EA and $\mathrm{A} 4 \mathrm{nB}$ were found to be $360.66 \mu \mathrm{g} / \mathrm{ml}, 157.13 \mu \mathrm{g} / \mathrm{ml}$ and 197.52 $\mu \mathrm{g} / \mathrm{ml}$. Hence, APLF-4 extracts strongly inhibited hydroxyl radical with IC 50 values as compared to APLF-3 extracts (fig. 4).

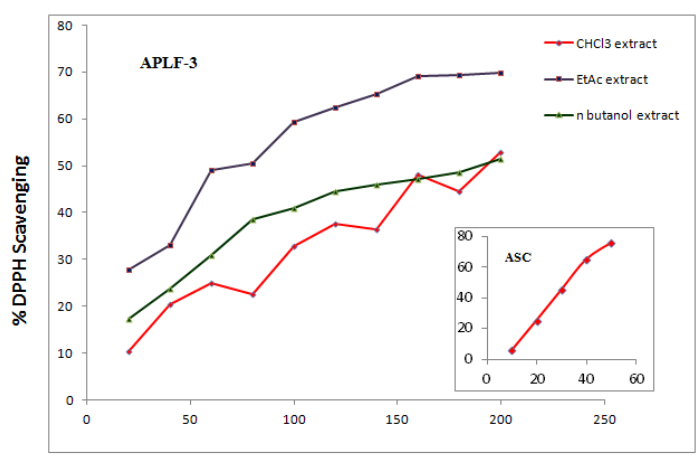

Concentration $(\mu \mathrm{g} / \mathrm{ml})$

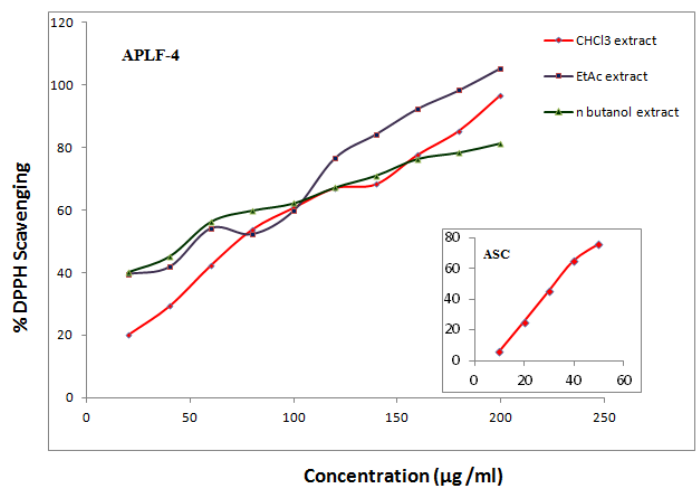

Fig. 3: Effect of ascorbic acid, APLF-3 and APLF-4 extracts on DPPH radical
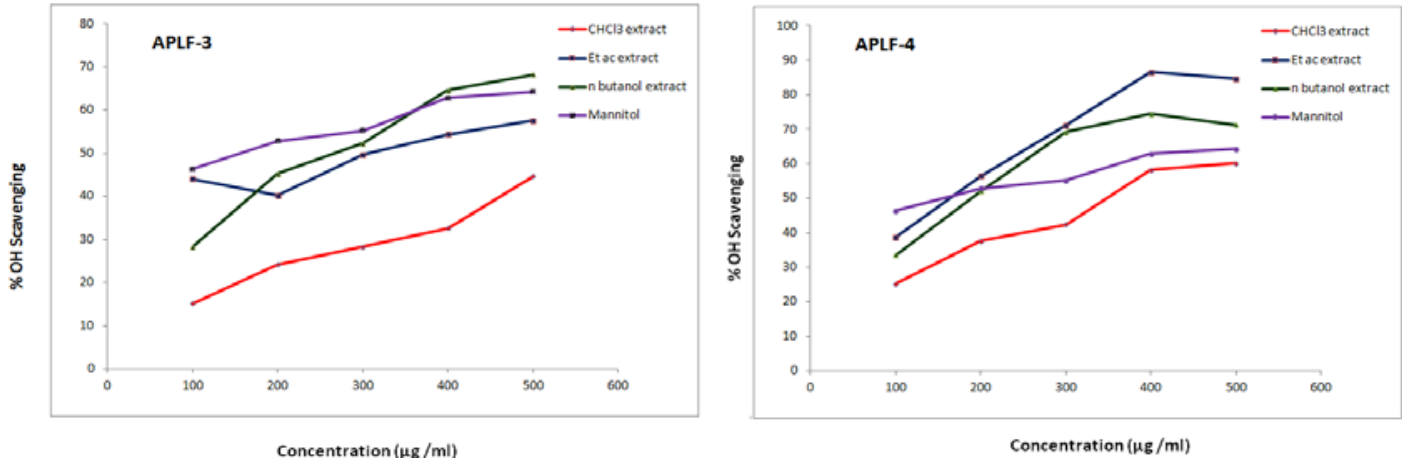

Fig. 4: Effect of mannitol, APLF-3 and APLF-4 extracts on hydroxyl radical
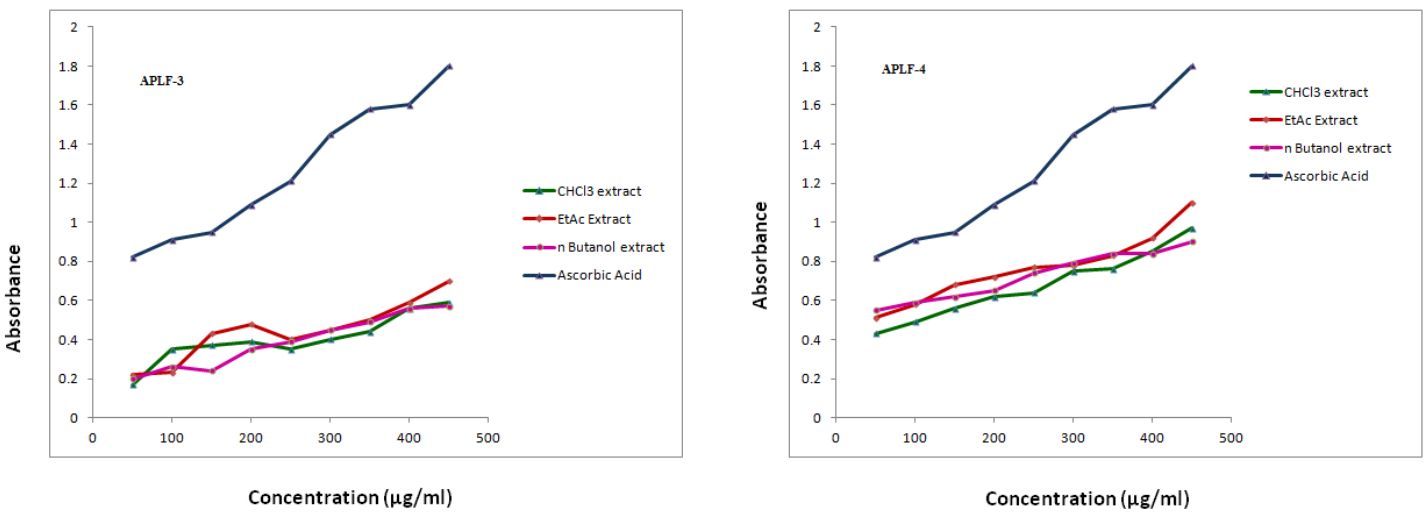

Fig. 5: Reducing power assay of ascorbic acid, APLF-3 and APLF-4 extracts

\section{Reducing power assay}

In this assay, Fe (III) reduction is often used as a significant indicator of electron donating activity which is an important mechanism of phenolic antioxidant action by breaking the radical chain by donating a hydrogen atom. Reducing the power of extracts of APLF-3 and APLF-4 (50$450 \mu \mathrm{g} / \mathrm{ml}$ ) increased with increase in concentration. The A4EA and $\mathrm{A} 4 \mathrm{nB}$ showed more effective reductive ability when compared to other 
extracts. The A4EA and A4nB showed the highest activity in a dosedependent manner as compared to the other extracts (fig. 5).

\section{Acute toxicity (LD50) studies}

Acute toxicity studies were carried out according to OECD guidelines (Up and Down method). No mortality was observed up to 2000 $\mathrm{mg} / \mathrm{kg}$ body weights were for A4EA and A4nB. Hence, doses of 50 $\mathrm{mg} / \mathrm{kg}$ and $100 \mathrm{mg} / \mathrm{kg}$ body weight were selected to assess the hepatoprotective activity of $\mathrm{A} 4 \mathrm{EA}$ and $\mathrm{A} 4 \mathrm{nB}$ extracts respectively.
Effect of APLF-4 on serum biochemical parameters in $\mathrm{CCl}_{4}$ induced hepatotoxicity in rats

Administration of $\mathrm{CCl}_{4}(2 \mathrm{ml} / \mathrm{kg}$ i. p.) significantly increased the levels of ALT, AST, ALP total and direct bilirubin, TG and total protein as compared to normal control. A4EA $(50 \mathrm{mg} / \mathrm{kg}$ and100 $\mathrm{mg} / \mathrm{kg})$ and $\mathrm{A} 4 \mathrm{nB}(50 \mathrm{mg} / \mathrm{kg}$ and $100 \mathrm{mg} / \mathrm{kg})$ reversed the elevated biochemical parameters as compared to $\mathrm{CCl}_{4}$ treated group $\left({ }^{* * *} \mathrm{P}<0.001\right)$ (table 2$)$.

Table 2: Effect of A4EA and $\mathrm{A4nB}$ on serum biochemical parameters in $\mathrm{CCl}_{4}$ induced hepatotoxicity in rats

\begin{tabular}{|c|c|c|c|c|c|c|c|}
\hline Groups & $\begin{array}{l}\text { ALT } \\
\text { (mg/dl) }\end{array}$ & $\begin{array}{l}\text { AST } \\
\text { (mg/dl) }\end{array}$ & $\begin{array}{l}\text { ALP } \\
\text { (mg/dl) }\end{array}$ & $\begin{array}{l}\text { Total Bilirubin } \\
\text { (mg/dl) }\end{array}$ & $\begin{array}{l}\text { Direct Bilirubin } \\
(\mathrm{mg} / \mathrm{dl})\end{array}$ & $\begin{array}{l}\text { Triglyceride } \\
\text { (mg/dl) }\end{array}$ & $\begin{array}{l}\text { Total } \\
\text { protein }\end{array}$ \\
\hline $\begin{array}{l}\text { Control } \\
(2 \mathrm{ml} / \mathrm{kg})\end{array}$ & $34.64 \pm 3.1$ & $131.9 \pm 3.6$ & $246.4 \pm 2.4$ & $0.25 \pm 0.02$ & $0.16 \pm 0.018$ & $45.10 \pm 1.50$ & $6.45 \pm 0.10$ \\
\hline $\begin{array}{l}\mathrm{CCl}_{4} \text { treated } \\
(2 \mathrm{ml} / \mathrm{kg})\end{array}$ & $183.2 \pm 2.2$ & $242.6 \pm 2.4$ & $324.3 \pm 2.2$ & $0.72 \pm 0.01$ & $0.52 \pm 0.024$ & $87.87 \pm 2.35$ & $3.71 \pm 0.089$ \\
\hline $\begin{array}{l}\text { Silymarin }+\mathrm{CCl}_{4} \\
(25 \mathrm{mg} / \mathrm{kg})\end{array}$ & $62.63 \pm 2.7^{* * *}$ & $159.0 \pm 3.9 * * *$ & $269.8 \pm 2.3^{* * *}$ & $0.51 \pm 0.02^{* * *}$ & $0.36 \pm 0.013^{* * *}$ & $45.32 \pm 1.64^{* * *}$ & $5.89 \pm 0.28^{* * *}$ \\
\hline $\begin{array}{l}\mathrm{A} 4 \mathrm{EA}+\mathrm{CCl}_{4} \\
(50 \mathrm{mg} / \mathrm{kg})\end{array}$ & $106.8 \pm 2.9^{* *}$ & $146.4 \pm 3.3^{* * *}$ & $311.1 \pm 3.1 *$ & $0.37 \pm 0.02^{* *}$ & $0.25 \pm 0.008^{* * *}$ & $77.55 \pm 1.04^{* *}$ & $5.89 \pm 0.59 * * *$ \\
\hline $\begin{array}{l}\mathrm{A} 4 \mathrm{EA}+\mathrm{CCl} 4 \\
(100 \mathrm{mg} / \mathrm{kg})\end{array}$ & $110.4 \pm 4.3^{* * *}$ & $190.3 \pm 3.5^{* * *}$ & $290.3 \pm 2.0^{* * *}$ & $0.30 \pm 0.02^{* * *}$ & $0.18 \pm 0.019 * * *$ & $63.94 \pm 0.89 * * *$ & $7.61 \pm 0.20^{* * *}$ \\
\hline $\begin{array}{l}\mathrm{A} 4 \mathrm{nB}+\mathrm{CCl}_{4} \\
(50 \mathrm{mg} / \mathrm{kg})\end{array}$ & $118.8 \pm 2.6^{* * *}$ & $145.7 \pm 3.1^{* * *}$ & $311.5 \pm 2.4^{*}$ & $0.38 \pm 0.02^{* * *}$ & $0.42 \pm 0.019 * *$ & $67.77 \pm 1.61^{* * *}$ & $5.53 \pm 0.17^{* *}$ \\
\hline $\begin{array}{l}\mathrm{A} 4 \mathrm{nB}+\mathrm{CCl}_{4} \\
(100 \mathrm{mg} / \mathrm{kg})\end{array}$ & $146.9 \pm 2.9 * * *$ & $170.8 \pm 2.0^{* * *}$ & $269.5 \pm 1.9 * * *$ & $0.50 \pm 0.02^{* * *}$ & $0.24 \pm 0.016^{* * *}$ & $56.97 \pm 1.56^{* * *}$ & $6.84 \pm 0.53^{* * *}$ \\
\hline
\end{tabular}

Each value represents mean \pm SEM $(\mathrm{n}=6){ }^{*} \mathrm{P}<0.05,{ }^{* *} \mathrm{P}<0.01,{ }^{* * *} \mathrm{P}<0.001$ compared to $\mathrm{CCl}_{4}$ treated group. One way ANOVA followed by Tukey's multiple comparison tests

\section{Effect of A4EA and A4nB on endogenous antioxidant enzyme}

The treatment of rats with $\mathrm{CCl}_{4}$ group showed decreased SOD and CAT levels and an increase in LPO level in terms of TBARS as compared to control. A4EA (100 mg/kg) and A4nB (50 mg/kg) increased the SOD levels showing significant values. A4nB $(50 \mathrm{mg} / \mathrm{kg}$ and $100 \mathrm{mg} / \mathrm{kg})$ increased the levels of CAT significantly. A4nB $(50 \mathrm{mg} / \mathrm{kg})$ significantly inhibited the in vivo lipid peroxidation (table 3).

Table 3: Effect of A4EA and A4nB on LPO, SOD and CAT levels in $\mathrm{CCl}_{4}$ induced rats

\begin{tabular}{|c|c|c|c|}
\hline Groups & $\begin{array}{l}\text { LPO level } \\
(\mu \mathrm{mol} / \mathrm{mg} / \text { protein })\end{array}$ & $\begin{array}{l}\text { SOD level } \\
(\mu \mathrm{mol} / \mathrm{mg} / \text { protein })\end{array}$ & CAT level ( $\mu \mathrm{mol} / \mathrm{mg} /$ protein) \\
\hline Control (2 ml $/ \mathrm{kg})$ & $13.65 \pm 0.78$ & $37.84 \pm 0.83$ & $64.70 \pm 0.97$ \\
\hline $\mathrm{CCl}_{4}$ treated $(2 \mathrm{ml} / \mathrm{kg})$ & $30.71 \pm 0.66$ & $21.75 \pm 0.23$ & $35.68 \pm 1.39$ \\
\hline Silymarin $(25 \mathrm{mg} / \mathrm{kg})$ & $15.75 \pm 0.80^{* * *}$ & $28.11 \pm 0.97 * * *$ & $51.60 \pm 1.04^{* * *}$ \\
\hline A4EA $(50 \mathrm{mg} / \mathrm{kg})$ & $26.68 \pm 0.56$ & $25.69 \pm 1.08$ & $42.20 \pm 1.47 *$ \\
\hline A4EA $100 \mathrm{mg} / \mathrm{kg}$ ) & $23.27 \pm 0.74^{* *}$ & $26.14 \pm 0.74 *$ & $39.91 \pm 1.51$ \\
\hline $\mathrm{A} 4 \mathrm{nB}(50 \mathrm{mg} / \mathrm{kg})$ & $23.96 \pm 0.72 *$ & $26.48 \pm 0.86^{*}$ & $45.34 \pm 1.07 * * *$ \\
\hline $\mathrm{A} 4 \mathrm{nB}(100 \mathrm{mg} / \mathrm{kg})$ & $20.52 \pm 1.55^{* * *}$ & $28.64 \pm 0.89 * * *$ & $50.75 \pm 0.82^{* * *}$ \\
\hline
\end{tabular}

Each value represents mean \pm SEM $(\mathrm{n}=6){ }^{*} \mathrm{P}<0.05$, ${ }^{* *} \mathrm{P}<0.01,{ }^{* * *} \mathrm{P}<0.001$ compared to $\mathrm{CCl}_{4}$ treated group. One way ANOVA followed by Tukey's multiple comparison tests

\section{Histopathology of liver}

Normal hepatic cell arrangement was observed in the normal liver. Central vein, portal tract, and normal kupffer cells showed no inflammation (fig. $6 \mathrm{~A}$ ). $\mathrm{In} \mathrm{CCl}_{4}$ treated group hepatocytes exhibited large degeneration of fatty cells, congestion of central vein and sinusoid, spotty necrosis, focal hemorrhage, ballooning and inflammation of hepatic cells (fig. 6B). In standard silymarin $(100 \mathrm{mg} / \mathrm{kg})$ treated group the hepatic globular structure was found to be normal. Mild central vein and sinusoidal congestion were noticed. Regeneration of hepatocytes was also found (fig. 6C). A4EA treated livers (50 mg/kg) exhibited normal rearrangement of hepatocytes surrounding the necrosis and fatty vacuoles (fig. 6D). A4EA treated livers $(100 \mathrm{mg} / \mathrm{kg})$ showed mild congestion of central vein and sinusoid. Mild inflammation and focal hemorrhage were seen, whereas no degeneration and ballooning of hepatic cells was observed (fig. $6 \mathrm{E})$. A4nB $(50 \mathrm{mg} / \mathrm{kg})$ treated livers showed decreased inflammation of hepatocytes. Mild ballooning and degeneration of injured liver were restored (fig. 6F). A4nB (100 mg/kg) treated livers also showed regeneration of hepatocytes with mild inflammation and ballooning (fig. 6G).

\section{PCR sequential analysis of APLF-3 and APLF-4}

The sequence of the ITS gene from sample APLF-3 and APLF-4 that of matching sequences from 10 nucleotide sequences were aligned by using the maximum likelihood method based on the Tamura-Nei model (fig. 7). The tree with the highest log likelihood (-999.5085) for APLF-3 and (-1106.5583) for APLF-4 is shown. There were a total of 572 positions in the final dataset for APLF-3 and 608 positions for APLF-4 respectively. Evolutionary analyses were conducted in MEGA5. The sequence of the ITS gene for APLF-3 and APLF-4 were compared with existing sequences in the NCBI database using the Blast $\mathrm{N}$ programme (fig. 8). Based on these results APLF-3 and APLF-4 were identified as Phyllosticta sp. ZLY2010 isolate M13 and Aspergillus tubingensis strain Cs/7/2 respectively. The microscopic view of the identified organisms is shown in fig. 9 and 10. 


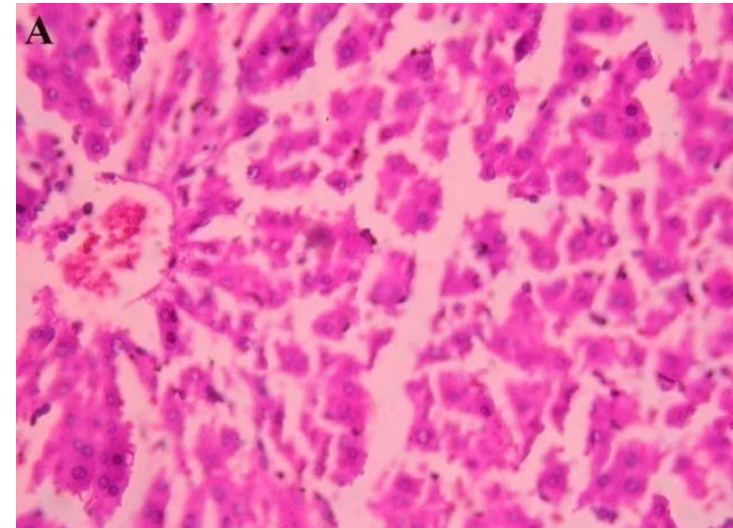

A. Normal liver

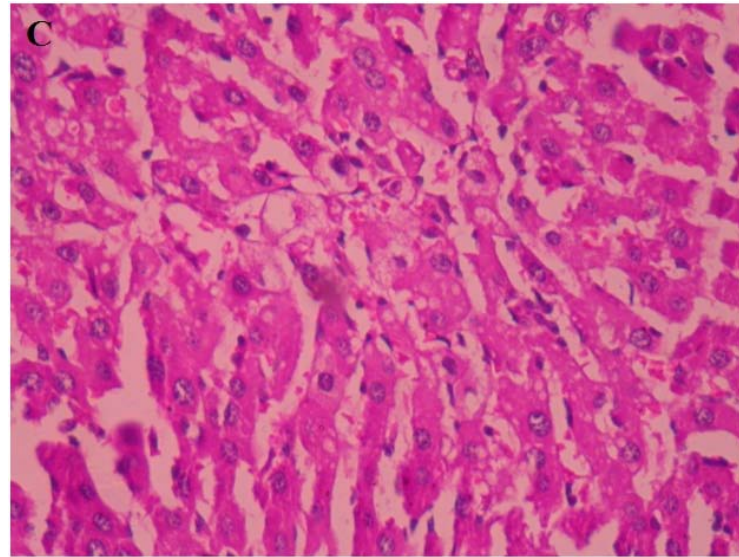

C. Silymarin treated rat liver

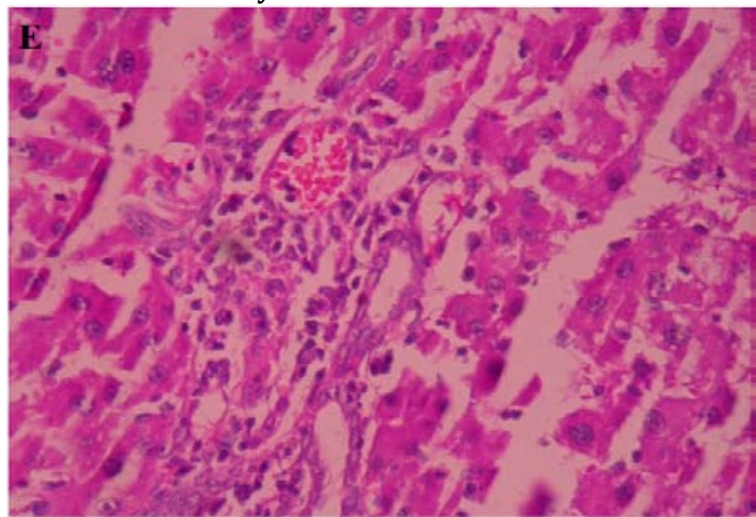

E. A4EA(50 mg/kg)

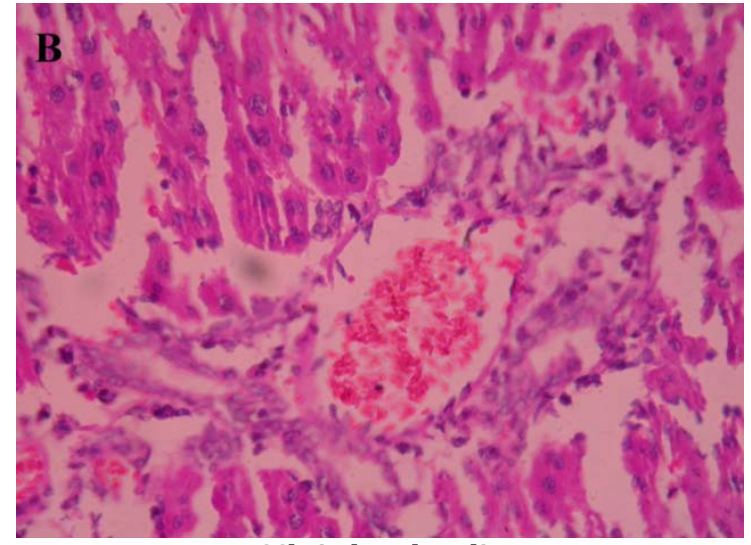

B. $\mathrm{CCl}_{4}$ induced rat liver

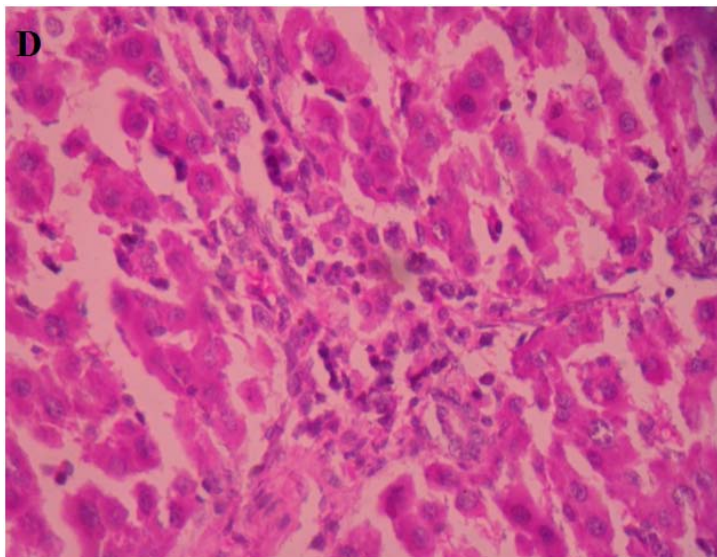

D. A4EA(50 mg/kg)

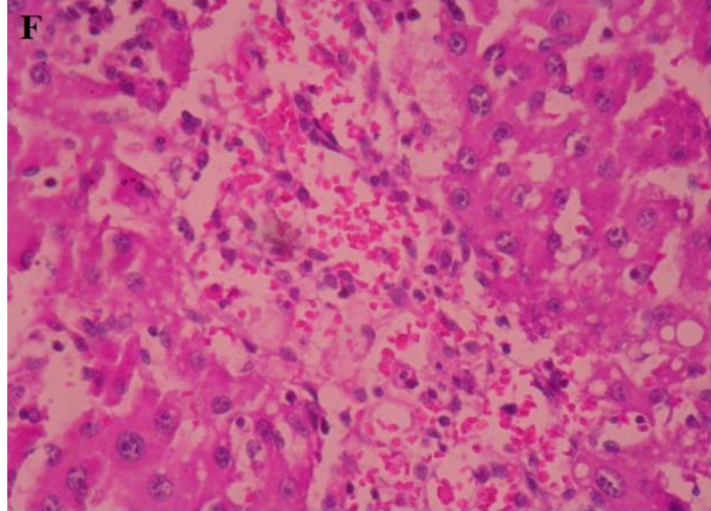

F. A4nB(50 mg/kg)

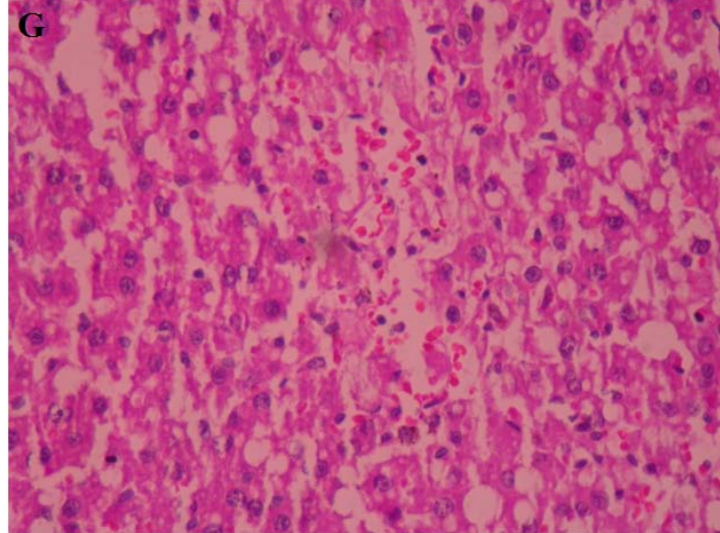

G. $A 4 n B(100 \mathrm{mg} / \mathrm{kg})$

Fig. 6: Histopathological sections of liver with $\mathrm{CCl}_{4}$ induced hepatotoxicity: A. Normal liver, $\mathrm{B}$. $\mathrm{CCl}_{4}$ induced rat liver, C. Silymarin treated rat liver, D. A4EA $(50 \mathrm{mg} / \mathrm{kg})$, E. A4EA(100 mg/kg), F. A4nB(50 mg/kg), G. A4nB (100 mg/kg) 


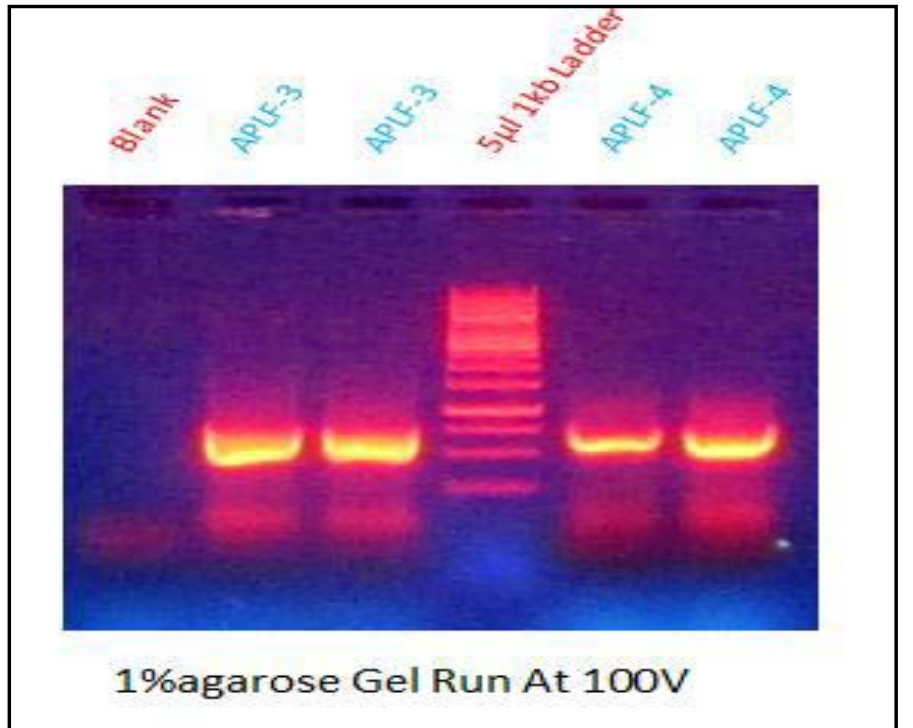

Fig. 7: Genomic DNA extracted from APLF-3 and APLF-4, run on 0.8\% Agarose gel electrophoresis and visualized with propidium iodide

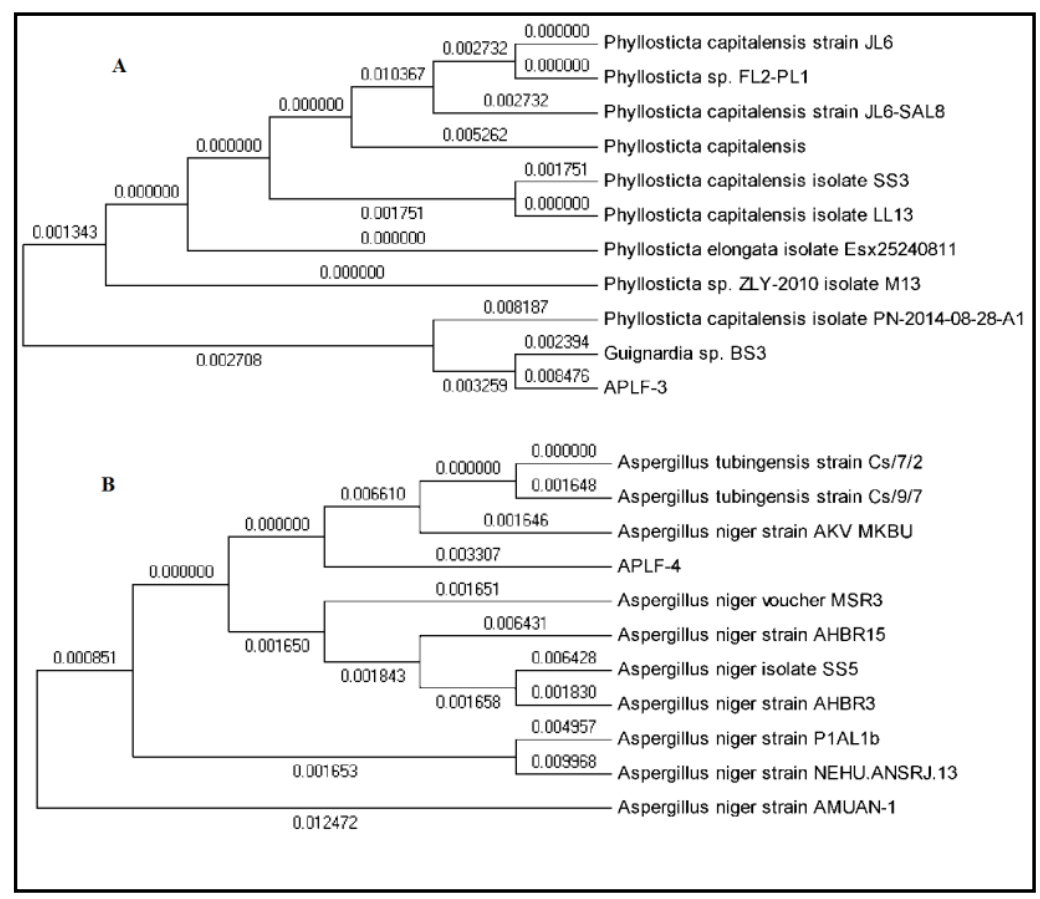

Fig. 8: Phylogenetic trees analysis of APLF-3 (A) and APLF-4 (B) were compared with existing sequences in the NCBI database using the BlastN program. The DNA sequence of APLF-3 matched with Phyllosticta sp. ZLY-2010 isolate M13 and APLF-4 matched with Aspergillus tubingensis strain $\mathrm{Cs} / 7 / 2$

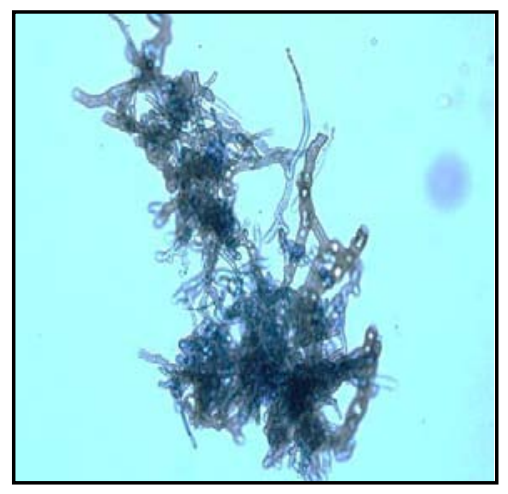

Fig. 9: APLF-3 identified as Phyllosticta sp. ZLY-2010 isolates M13

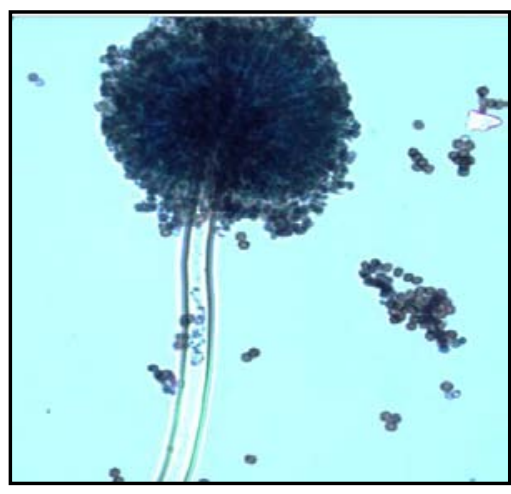

Fig. 10: APLF-4 identified as Aspergillus tubingensis strain $C s / 7 / 2$ 


\section{HPTLC fingerprint}

HPTLC fingerprinting of A4EA and A4nB scanned at wavelength $254 \mathrm{~nm}$ showed the presence of six and thirteen polyvalent secondary metabolites respectively. The range of $\mathrm{Rf}$ values starts from 0.01 to 0.99 in which the highest concentration of the metabolite was found to be $27.53 \%$ and $35.75 \%$ with Rf values of 0.93 and 0.61 respectively. However, at $366 \mathrm{~nm}, \mathrm{~A} 4 \mathrm{EA}$ and A4nB reveled nine and thirteen secondary metabolites at a range of $\mathrm{Rf}$ values starting from 0.01 to 0.99 respectively. The highest concentration was found to be $45.88 \%$ with Rf value of 0.08 for A4EA and $14.31 \%$ with $\mathrm{Rf}$ value of 0.31 for $\mathrm{A} 4 \mathrm{nB}$ respectively. After derivatization at $620 \mathrm{~nm}, \mathrm{~A} 4 \mathrm{EA}$ and $\mathrm{A} 4 \mathrm{nB}$ showed the presence of eleven and thirteen polyvalent secondary metabolites respectively. The range of $\mathrm{Rf}$ values starts from 0.00 to 0.94 in which highest concentration of the metabolite was found to be $45.88 \%$ and $30.23 \%$ with $\mathrm{Rf}$ values of 0.08 and 0.03 respectively (fig. 11 and 12).

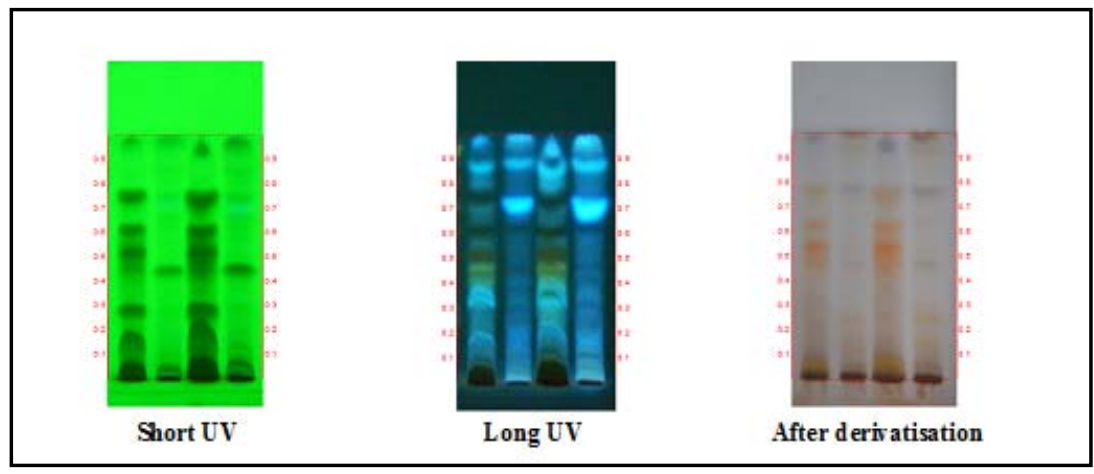

Fig. 11: HPTLC of A4EA and A4nB extracts at $254 \mathrm{~nm}, 366 \mathrm{~nm}$ and post derivatization, Track 1-A4EA-3 $\mu \mathrm{l}$, Track 2-A4NB-6 $\mu \mathrm{l}$, Track 3A4EA-3 $\mu$, Track 4-A4NB-6 $\mu \mathrm{l}$

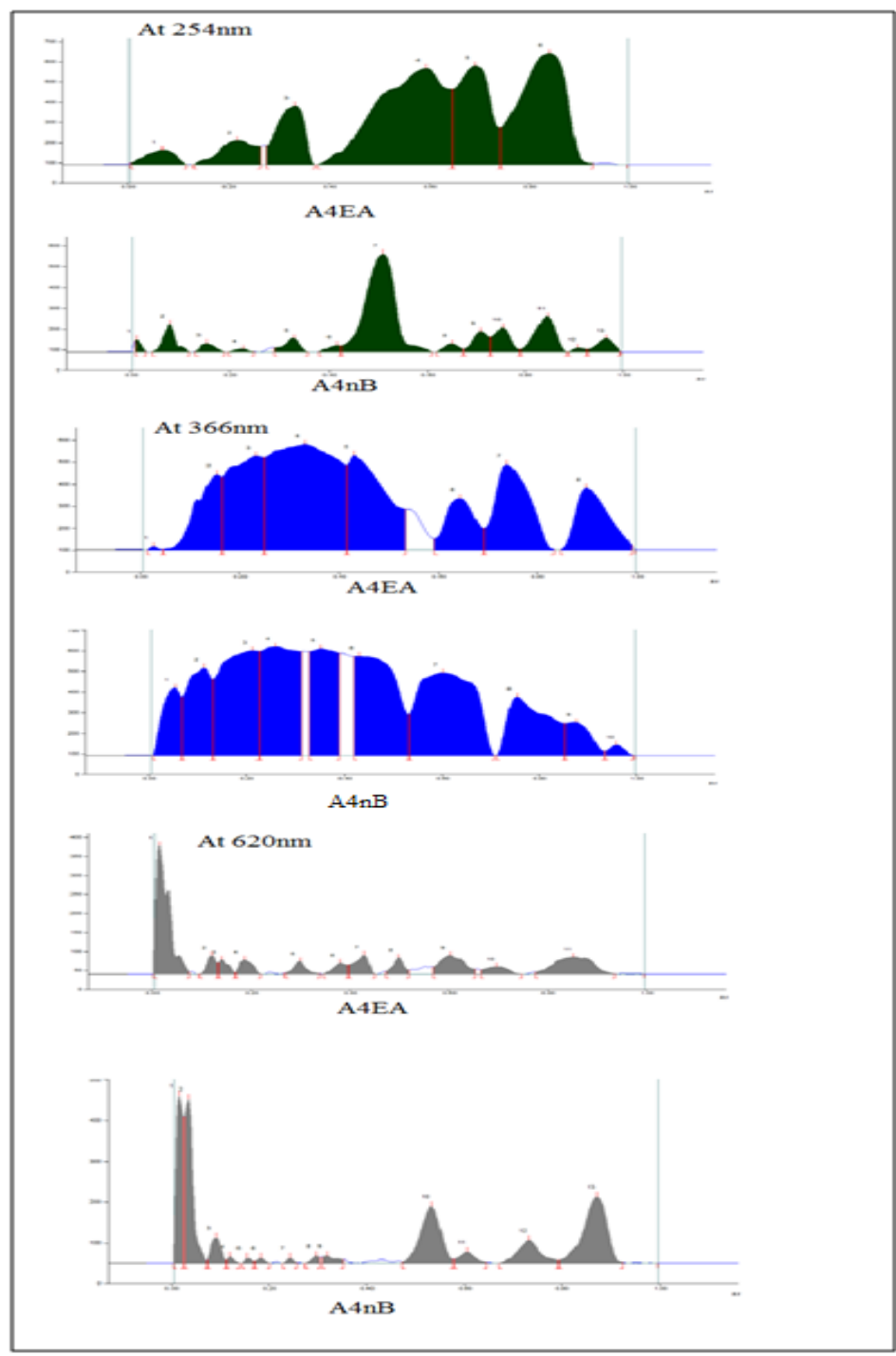

Fig. 12: Chromatograms of A4EA and A4nB extracts at $254 \mathrm{~nm}, 366 \mathrm{~nm}$ and $620 \mathrm{~nm}$ 


\section{DISCUSSION}

As there is an increasing interest relating to the plant-microbe association, especially in the structure and function of endophytes, which occupy plants without apparently causing any damage [34] Endophytic microbes are relatively common in all families of plants from polar to tropical regions. All classes of vascular plants and grasses are found to endow with endophytic organisms. Endophytes trigger plant growth by various mechanisms as nitrogen fixation, inorganic phosphate solubilization, siderophore production, micronutrient supply, photosynthetic activity and phytostimulation [35]. Endophytic microbes were reported from various plants existing in different ecosystems. Some of the chemically complex structures that are of dual endophyte/plant origin and which have been investigated in last few decades include paclitaxel [36], vinca alkaloids [37], camptothecin [38], and podophyllotoxin [39] Therefore, endophytes are potential sources of plant-associated natural products.

In this study, APLF-3 and APLF-4 are the two endophytic fungi, isolated from the Andrographis paniculata leaves. By sequential analysis, APLF-3 and APLF-4 were identified as Phyllosticta sp. ZLY2010 isolate M13 and Aspergillus tubingensis strain Cs/7/2.

Phyllosticta is a genus of fungi. Many of the species of this genus are common and important plant pathogens [40]. They infect the foliage causing tannish grey leaf spots with dark brown to purple borders. The endophytic fungus Phyllosticta is one of the members of Dothideomycetes, causing disease in economic crops. Phyllosticta was screened for the degradation of lignocellulosic biomass of commercial relevance, such as rice straw, rice husk, sorghum, wheat straw, miscanthus, lavender flower, and lavender straw. Phyllosticta capitalensis is a new strain for the production of lignocellulosic enzymes during growth on cheap agro-industrial biomass. Phyllosticta species are known to produce various types of secondary metabolites. Five new metabolites, namely (+)-(5S, 10S)-4'hydroxymethylcyclozonarone, 3-ketotauranin, 3R-hydroxytauranin, 12-hydroxytauranin, and phyllospinarone were isolated from Phyllosticta spinarum, a fungal strain endophytic in Platycladus orientalis [41]. Phyllosticta derivatives were isolated from Phyllosticta cirsii exhibits growth-inhibitory activity in five cancer cell lines [2]. Many authors reported more than 100 isolates belonging to Phyllosticta (Teleomorph Guignardia), with a special focus on Phyllosticta citricar and Guignardia mangiferae occurring on Citrus [43]. Phyllosticta species isolated from the leaves of Guazuma tomentosa also showed antioxidant activity [44].

Aspergillus tubingensis is a darkly pigmented member of the genus Aspergillus nigri which also includes Aspergillus niger and Aspergillus awamori amongst a total of 25 species. It is often confused with Aspergillus niger due to their similar morphology and habitat [45]. Because of the scarcity of mycotoxin produced by Aspergillus tubingensis, it has been explored for use in biotechnology and industrial applications. Aspergillus tubingensis is generally recognized as safe by the American food and drug administration (FDA) [46]. A pyrone named rubrofusarin was isolated from fermentation of Aspergillus tubingensis in Lycium ruthenicum. It showed strong inhibitory activity against Escherichia coli [47]. Four new dimeric naphtho- $\gamma$-pyrones, named rubasperone $\mathrm{D}$, rubasperone $\mathrm{E}$, rubasperone $\mathrm{F}$ and its atropisomer rubasperone $\mathrm{G}$, together with four known monomeric naphtho- $\gamma$-pyrones, TMC 256 A1, rubrofusarin B, fonsecin, and flavasperone were isolated from the mangrove endophytic fungus Aspergillus tubingensis (GX1-5E) cultivated in solid rice medium. Rubrofusarin $\mathrm{B}$ displayed inhibitory activities against tumor cell lines of MCF-7, MDA-MB-435, Hep3B, Huh7, SNB19, and U87 MG with IC50 values between 19.92 and $47.98 \mu \mathrm{M}$ [48].

Authors have reported that endophytic fungi, Aspergillus tubingensis and other Aspergillus species showed activity against 5 bacterial and 2 fungal strains. These endophytic fungi were isolated from Eugenia jambolana Lam. (Syzygium cumini) [49]. Preliminary phytochemical analysis of different extracts of APLF-3 and APLF-were found to contain flavonoids, alkaloids, triterpenoid, and tannins.

Antioxidants play a very important role in preventing cell damage. The diets containing antioxidants are recommended for health improvement as naturally derived antioxidant could delay or provide protection to living organisms from damage. Reactive oxygen species (ROS), e. g., $\mathrm{O}_{2}-$ and $\mathrm{OH}-$, are byproducts of normal metabolism and are found in all types of organisms [50]. Free radical scavenging activity by various models such as DPPH, hydroxyl free radical and reducing power was studied. DPPH is a stable, synthetic radical not shattering in water, methanol, or ethanol. At $517 \mathrm{~nm}$, the DPPH has capability to receive an electron or hydrogen from antioxidant molecules to become a stable diamagnetic molecule [51]. Reaction with DPPH radicals by $\mathrm{A} 4 \mathrm{C}, \mathrm{A} 4 \mathrm{EA}$ and $\mathrm{A} 4 \mathrm{nB}$ showed significant scavenging activity as compared to A3C, A3EA and A3nB. However, Increase in the concentration of $\mathrm{A} 4 \mathrm{C}, \mathrm{A} 4 \mathrm{EA}$ and $\mathrm{A} 4 \mathrm{nB}$ showed a decrease in the DPPH concentration.

The hydroxyl radicals are produced in mitochondria and endoplasmic reticulum due to fenton reactions, fatty acids oxidation and detoxification of xenobiotic. The endophytic extracts exhibited hydroxyl radical scavenging activity in a dose dependent manner. This may be due to inhibition of deoxyribose degradation and chelating the iron ions which prevents complexation with the deoxyribose and imparting them inactive in a Fenton reaction. A4C, A4EA and A4nB diminished the metal concentration in Fenton reaction showing the chelating effect on ferrous ions with a comparison to EDTA.

The reducing power of extracts of APLF-3 and APLF-4 (50-450 $\mu \mathrm{g} / \mathrm{ml}$ ) and ascorbic acid, increased steadily with the increase in concentration. The A4EA showed more effective reductive ability when compared to other endophytic extracts. This may be due to mono and dihydroxyl substitutions in the aromatic ring, which possess potent hydrogen donating abilities.

APLF-4 extracts were found to be significant with minimum $\mathrm{IC}_{50}$ values as compared to APLF-3 extracts. Hence, only A4EA and A4nB showing significant in vitro antioxidant activity were selected for in vivo hepatoprotective activity in $\mathrm{CCl}_{4}$ induced model. The nontoxicity of A4EA and A4nB was concluded by acute toxicity studies as per OECD guidelines. Therefore, the doses selected for the in vivo studies were $50 \mathrm{mg} / \mathrm{kg}$ and $100 \mathrm{mg} / \mathrm{kg}$.

In the present study, the effect of A4EA and A4nB $(50 \mathrm{mg} / \mathrm{kg}$ and $100 \mathrm{mg} / \mathrm{kg}$ ) on the biochemical parameters were determined in albino rats. In the study, a single dose of $\mathrm{CCl}_{4}$ injection increased the levels of AST, ALT, ALP, total and direct bilirubin, TG and a decreased the protein level because of its release into the blood in the $\mathrm{CCl}_{4}$ induced hepatotoxic rats.

Metabolically $\mathrm{CCl}_{4}$ is activated by the cytochrome P-450 dependent mixed oxidase in the endoplasmic reticulum forming trichloromethyl radicals $\left(\mathrm{CCl}_{3}\right)$ [52]. The results confirm that covalent binding of the $\mathrm{CCl}_{3} *$ radical to cell components initiates the inhibition of lipoprotein secretion causing steatosis, whereas reaction with oxygen, to form trichloromethyl radicals initiating lipid peroxidation. It may result in loss of calcium homeostasis and, ultimately, apoptosis and cell death. In this study, administration of A4EA, A4nB (50 mg/kg and $100 \mathrm{mg} / \mathrm{kg}$ ) and silymarin caused a decrease in the activities of AST, ALT and ALP.

Serum bilirubin and total protein levels are related to the function of the hepatic cell. Serum bilirubin synthesized by the liver is the highest concentration protein in plasma. It transports many small molecules in the blood. It also prevents the fluid in the blood from leaking out into the tissues. The present study exhibited a significant decrease in the levels of serum bilirubin in A4EA, A4nB $(50 \mathrm{mg} / \mathrm{kg}$ and $100 \mathrm{mg} / \mathrm{kg}$ ) and silymarin treated rats when compared to $\mathrm{CCl}_{4}$ treated group rats. Decreased serum bilirubin produces increased protection of the liver.

At higher concentrations, Reactive oxygen species (ROS) having reactive oxygen and peroxide ions causes detrimental effects to the molecules as DNA, RNA, protein and lipids, mortality in humans. In various diseased states, antioxidants prevent the outset of such diseases. They contest against oxidative stress through numerous physiological processes. Some of the endogenous antioxidant enzymes embraced are superoxide dismutase, catalase, and glutathione peroxidase and reduced glutathione [53].

Lipid peroxidation elevation is one of the major results of $\mathrm{CCl}_{4}$ induced hepatotoxicity. $\mathrm{CCl}_{4}$ administration $(0.5 \mathrm{ml} / \mathrm{kg}$ b. w) 
increased malondialdehyde (MDA), a lipid peroxidation product in the liver of rats. This enhanced lipid peroxidation leads to tissue damage and failure of antioxidant defense mechanisms to prevent the excessive free radical formation. This finally leads to cell death. Our results revealed that treatment of rats for $7 \mathrm{~d}$ with A4EA and $\mathrm{A} 4 \mathrm{nB}$ along with $\mathrm{CCl}_{4}$ significantly reversed these changes. This may be due to the antioxidant action of A4EA and A4nB [54]. A rise in ROS production was observed on the administration of $\mathrm{CCl}_{4}$ as depicted by a significant decrease in levels of SOD and CAT. After administration of A4EA and $\mathrm{A} 4 \mathrm{nB}(50$ and $100 \mathrm{mg} / \mathrm{kg}$ ) showed a remarkable increase in the SOD and CAT enzymatic activity. The protein expression levels were also determined by Western blotting analysis of liver tissue. $\mathrm{CCl}_{4}$ treatment produced significant down regulations of the protein expression levels of SOD and CAT compared with the normal control. A4EA and A4nB (50 and 100 $\mathrm{mg} / \mathrm{kg}$ ) administration significantly improved protein expressions of the two antioxidant enzymes in the liver. Our results suggested that $\mathrm{A} 4 \mathrm{EA}$ and $\mathrm{A} 4 \mathrm{nB}$ (50 and $100 \mathrm{mg} / \mathrm{kg}$ ) may decline oxidative stress by elevating the activity and protein expression of the antioxidant enzymes in vivo.

Normal hepatic cell arrangement was seen in the normal liver as compared to $\mathrm{CCl}_{4}$ group as hepatocytes exhibited large degeneration of fatty cells, congestion of central vein and sinusoid, spotty necrosis, focal hemorrhage, ballooning and inflammation of hepatic cells. A4EA $(50 \mathrm{mg} / \mathrm{kg}$ and $100 \mathrm{mg} / \mathrm{kg}$ ) showed normal rearrangement of hepatocytes round the necrosis and fatty vacuoles, with mild congestion of central vein and sinusoid. A4nB $(50 \mathrm{mg} / \mathrm{kg}$ and 100 $\mathrm{mg} / \mathrm{kg}$ ) showed decreased inflammation of hepatocytes. Mild ballooning and degeneration of injured liver were restored. These observations showed that A4EA and A4nB $(50 \mathrm{mg} / \mathrm{kg}$ and 100 $\mathrm{mg} / \mathrm{kg}$ ) reversed the toxic effects of $\mathrm{CCl}_{4}$ on hepatic architecture.

HPTLC fingerprinting analysis is a significant and substantial method for identification of the presence of various secondary metabolites. It is a liner, precise and accurate method for identification, authentication, and characterization of the medicinal plant extracts. Novel drugs can be formulated by the isolation of active compounds by HPTLC for treating various diseases [55]. The development of HPTLC fingerprint for A4EA and A4nB revealed the direction for the quality control of phytoconstituents from extracts.

\section{CONCLUSION}

A4EA and $\mathrm{A} 4 \mathrm{nB}$ of leaf endophytic fungus, Aspergillus tubingensis strain $C s / 7 / 2$ isolated from Andrographis paniculata exhibited antioxidant and hepatoprotective activity in $\mathrm{CCl}_{4}$ induced hepatotoxicity. HPTLC fingerprinting analysis revealed the chemical diversity of A4EA and A4nB of APLF-4.

\section{ACKNOWLEDGMENT}

The authors are thankful to the President, Soniya Education Trust and Principal, SET's College of Pharmacy, Dharwad for encouragement, support and providing the necessary facilities to carry out the research work. We are also thankful to Dr. G R Hegde, Karnatak University, Dharwad (India) for identification of the plant.

\section{AUTHORS CONTRIBUTIONS}

All the authors have contributed equally

\section{CONFLICT OF INTERESTS}

The author(s) declare(s) that they have no conflict of interest to disclose

\section{REFERENCES}

1. Tian S, Yang Y, Liu K, Xiong Z, Xu L, Zhao L. Antimicrobial metabolites from a novel halophilic Actinomycete nocardiopsis terrae YIM 90022. Nat pro res 2014;28:344-6.

2. Egamberdieva D, Berg G, Lindstrom K, Rasanen La. Coinoculation of Pseudomonas sp. with Rhizobium improves growth and symbiotic performance of fodder galega (Galega orientalis Lam.). Euro J of Soil Bio 2010;46:269-72.

3. Strobel G, Daisy B. Bioprospecting for microbial endophytes and their natural products. Micro and Molr Bio Rev 2003;67:491-502.
4. Katoch M, Singh A, Singh G, Wazir P, Kumar R. Phylogeny, antimicrobial, antioxidant and enzyme-producing potential of fungal endophytes found in Viola odorata. Annals Microl 2017;67:529-40.

5. Swarnalatha Y, Saha B. Enhanced cytotoxic activity of endophytic bacterial extracts from Adhatoda beddomei leaves in A549 lung cancer cell lines. J Cancer Res Thera 2016;12:1284.

6. Fuchs B, Krischke M, Mueller MJ. Herbivore-specific induction of defense metabolites in a grass endophyte association. Funct Ecol 2017;31:318-24.

7. Eidi A, Mortazavi P, Bazargan M, Zaringhalam J. Hepatoprotective activity of cinnamon ethanolic extract against CCI4induced liver injury in rats. Exp Clin Sci J 2012;11:495.

8. Avinash KS, Krishnamurthy YL. Cytotoxic activity of endophytic fungi HHPCYL03 isolated from Cymbopogon flexuosus nees ex steud. Int J Curr Pharm Res 2015:7:70-2.

9. Raval PR, Raval RM. Treatment of infective hepatitis. Where biomedicine has no answers, ayurveda has. Ancient Sci Life 2016;35:176

10. Rao YK, Vimalamma G, Rao CV, Tzeng YM. Flavonoids and andrographolides from Andrographis paniculata. Phytochemistry 2004;65:2317-21.

11. Ghosh N, Ghosh R, Mandal V, Mandal SC. Recent advances in herbal medicine for the treatment of liver diseases. Pharma-Bio 2011;49:970-88.

12. Arunachalam C, Gayathri P. Studies on bioprospecting of endophytic bacteria from the medicinal plant of Andrographis paniculata for their antimicrobial activity and antibiotic susceptibility pattern. Int J Curr Pharma Res 2010;2:63-8.

13. Katoch M, Singh G, Sharma S, Gupta N, Sangwan PL, Saxena AK. Cytotoxic and antimicrobial activities of endophytic fungi isolated from Bacopa monnieri (L.) pennell (Scrophulariaceae). BMC Complementary Altern Med 2014;14:52.

14. Kumar S, Kaushik N. Endophytic fungi isolated from oilseed crop Jatropha curcas produces oil and exhibit antifungal activity. PloS One 2013;8:e56202.

15. Wicklow DT, Joshi BK, Gamble WR, Gloer JB, Dowd PF. Antifungal metabolites (monorden, monocillin IV, and cerebrosides) from Humicola fuscoatra Traaen NRRL 22980, a mycoparasite of Aspergillus flavus sclerotia. Appl Environ Microl 1998;64:4482-4.

16. Kokate CK, Purohit AP, Gokhale SB. Practical pharmacognosy. 4th Ed. Pune, Nirali Prakashan; 2005. p. 262-3.

17. Khandelwal KR. Practical pharmacognosy techniques and experiments. $9^{\text {th }}$ Ed. Pune, Nirali Prakashan; 2002. p. 149-60.

18. Astrid L. Preparation of lactophenol cotton blue slide mounts. Comm Eye Health 1999;12:24.

19. Junichi K, Makoto U, Sakae A. PCR-mediated detection of endophytic and phytopathogenic fungi from Needles of the Japanese black pine, Pinus thunbergii. Open J Forestry 2015;5:431-42.

20. Mathur SB, Kognsdal O. Common laboratory seed health testing methods for detecting Fungi (first Ed.) Inter seed testing association, Copenhagen, Denmark; 2003.

21. Saitou N, Nei M. The neighbor-joining method, a new method for reconstructing phylogenetic trees. Mol Biol Evol 1987;4:406-25.

22. Kim J, Rohlf Sokal RR. The accuracy of phylogenetic estimation using the neighbor-joining method. Evolution 1993;47:1486.

23. Harborne AJ. Phytochemical methods a guide to modern techniques of plant analysis. Springer sci and busi media; 1998.

24. Wagner $H$, Bladt S. Plant drug analysis. a thin layer chromatography atlas. Springer Sci Business Med; 1996.

25. Coruh N, Celep AS, Ozgokce F. Antioxidant properties of Prangos ferulacea (L.) Lindl., Chaerophyllum macropodum boiss and Heracleum persicum desf from apiaceae family used as food in Eastern Anatolia and their inhibitory effects on glutathioneS-transferase. Food chem 2007;100:1237-42.

26. Halliwell B, Gutteridge JMC, Aruoma OI. The deoxyribose method, a simple 'test tube' assay for determination of rates constants for reactions of hydroxyl radical. Anal Biochem 1987; 165:215-24.

27. Oyaizu M. Studies on products of the browning reaction. Antioxidative activities of products of browning reaction prepared from glucosamine. Japanese J Nutr 1986;4:307-15. 
28. Suja SR, Latha PG, Pushpangadan P, Rajasekharan S. Evaluation of hepatoprotective effects of Helminthostachys zeylanica (L.) hook against carbon tetrachloride-induced liver damage in Wistar rats. J Ethnopharma 2004;92:61-6.

29. Banerjee D, Maity B, Nag SK, Bandyopadhyay SK, Chattopadhyay S. Healing potential of Picrorhiza kurroa (Scrofulariaceae) rhizomes against indomethacin-induced gastric ulceration. a mechanistic exploration. BMC Complementary Altern Med 2008;8:3.

30. Flohe 0. Superoxide dismutase assays. In: Methods in enzmology (L Packer Ed) Academic Press: New York; 1984; 105:93-104.

31. Claiborne A. Handbook of methods for oxygen radical research. CRC Press; London: 1985. p. 283-4.

32. Lowry $\mathrm{OH}$, Rosebrough NJ, Farr AL, Randall RJ. Protein measurement with the folin phenol reagent. J Biochem 1951;193:265-75.

33. Galigher AE, Kozloff EN. In: Essentials of practical microtechnique. 2nd Edn. Lea and Febiger, Philadelphia; 1971. p. 77-9.

34. Deeb B, Fayez K, Gherbawy Y. Isolation and characterization of endophytic bacteria from Lectranthus tenuiflorus medicinal plant in Saudi Arabia desert and their antimicrobial activities. J Plant Inter 2013;8:56-64.

35. Gaiero JR, McCall CA, Thompson KA, Day NJ, Best AS, Dunfield KE. Inside the root microbiome bacterial root endophytes and plant growth promotion. Am J Bot 2013;100:1738-50.

36. Yang X, Zhang L, Guo B. Preliminary study of a vincristineproducing endophytic fungus isolated from leaves of Catharanthus roseus. Chintrad Herb Drug 2004;35:79-81.

37. Ueda JY, Tezuka Y, Banskota AH, Le Tran Q, Tran QK, Harimaya $\mathrm{Y}$, et al. Antiproliferative activity of vietnamese medicinal plants. Bio Pharma Bull 2002;25:753-60.

38. Maiya S, Grundmann A, Li X, Li SM, Turner G. Identification of a hybrid PKS/NRPS required for pseurotin a biosynthesis in the human pathogen Aspergillus fumigatus. Chembiochem 2007; 8:1736-43.

39. Kour A, Shawl AS, Rehman S, Sultan P, Qazi PH, Suden P, et al. Isolation and identification of an endophytic strain of Fusarium oxysporum producing podophyllotoxin from Juniperus recurva. World J Microl Biotech 2008;24:1115-21.

40. University of Georgia. Plant Pathology Phyllosticta; 2015.

41. Wijeratne EK, Paranagama PA, Marron MT, Gunatilaka MK, Arnold AE, Gunatilaka AL. Sesquiterpene quinones and related metabolites from Phyllosticta spinarum, a fungal strain endophytic in Platycladus orientalis of the sonoran desert. J Nat Prod 2008;71:218-22.
42. Evidente A, Cimmino A, Andolfi A, Vurro M, Zonno MC, Cantrell $\mathrm{CL}$, et al. Phyllostictines A-D, oxazatricycloalkenones produced by Phyllosticta cirsii, a potential mycoherbicide for Cirsium arvense biocontrol. Tetrahedron 2008;64:1612-9.

43. Glienke C, Pereira OL, Stringari D, Fabris J, Kava-Cordeiro V, Galli-Terasawa L, et al. Endophytic and pathogenic Phyllosticta species, with reference to those associated with Citrus Black Spot. Persoonia. Mol Phylogeny Evolution Fungi 2011;26:47.

44. Srinivasan K, Jagadish LK, Shenbhagaraman R, Muthumary J. Antioxidant activity of endophytic fungus Phyllosticta sp. isolated from Guazuma tomentosa. J Phytol 2010;2:37-41.

45. Oisewacz. Heinz industrial applications. New York. SpringerVerlag Berlin Heidelberg; 2002. p. 264-5.

46. Samson RA, Visagie CM, Houbraken J, Hong SB, Hubka V, Klaassen $\mathrm{CH}$, et al. Phylogeny, identification and nomenclature of the genus Aspergillus. Stud Mycol 2014;78:141-73.

47. Ma YM, Li T, Ma CC. A new pyrone derivative from an endophytic Aspergillus tubingensis of Lycium ruthenicum. Nat Prod Res 2016;30:1499-503.

48. Huang HB, Xiao ZE, Feng XJ, Huang $\mathrm{CH}$, Zhu X, Ju JH, et al. Cytotoxic Naphtho- $\gamma$-pyrones from the Mangrove endophytic fungus Aspergillus tubingensis (GX1-5E). Helv Chim Acta 2011;94:1732-40.

49. Yadav M, Yadav A, Kumar S, Sharma D, Yadav JP. Evaluation of in vitro antimicrobial potential of endophytic fungi isolated from Eugenia Jambolana Lam. Int J Pharm Pharm Sci 2014;6:208-11.

50. Vipin N, Archana G, Dinesh K. Isolation and characterization of endophytic fungi from Calotropis procera for their antioxidant activity. Asian J Pharm Clin Res 2017;10:254-8.

51. Soare JR, Dinis TC, Cunha AP, Almeida L. Antioxidant activities of some extracts of Thymus zygis. Free Rad Res 1997;26:469-78.

52. De Groot H, Noll T. The crucial role of low steady state oxygen partial pressures in haloalkane free-radical-mediated lipid peroxidation. Possible implications in haloalkane liver injury. Biochem Pharma 1986;35:15-9.

53. Bahar E, Ara J, Alam M, Nath B, Bhowmik U, Runi N. In vitro antioxidant and thrombolytic activity of methanol extract of Sida acuta. J Pharmacogn Phytochem 2013;2:125-33.

54. Adewale OB, Adekeye AO, Akintayo CO, Onikanni A, Sabiu S. Carbon tetrachloride $\left(\mathrm{CCl}_{4}\right)$-induced hepatic damage in experimental sprague dawley rats. Antioxidant potential of Xylopia aethiopica. J Phytopharma 2014;3:118-23.

55. Elangovan NM, Dhanarajan MS, Elangovan I. Preliminary phytochemical screening and HPTLC fingerprinting profile of leaf extracts of Moringa oleifera and Phyllanthus emblica. Int Res J Pharm Biosci 2015;2:32-40. 